\title{
Wady i zalety wypełniania kanałów gutaperką termoplastyczną - przegląd piśmiennictwa
}

\author{
Advantages and disadvantages of root canal obturation with thermoplasticized \\ gutta-percha - literature review
}

\author{
Zakład Stomatologii Zachowawczej Przedklinicznej i Endodoncji Przedklinicznej
}

Pomorski Uniwersytet Medyczny w Szczecinie

DOI: http://dx.doi.org/10.20883/df.2017.9

\begin{abstract}
Streszczenie
Nowoczesne metody wypełniania kanałów korzeniowych za pomocą gutaperki uplastycznionej cieplnie pozwalają na wypełnienie systemu kanałowego w trzech wymiarach. Pomimo zalet systemów gutaperki uplastycznionej termicznie należy zauważyć, że rozgrzana gutaperka wprowadzona do kanału korzeniowego powoduje wzrost temperatury na zewnętrznej powierzchni korzenia wypełnianego zęba. Zęby stałe niedojrzałe, zęby o cienkich ścianach korzenia (zęby sieczne żuchwy) lub zęby z resorpcją wewnętrzną są trudnymi sytuacjami klinicznymi, w których lekarz dentysta musi podjąć decyzję o metodzie wypełnienia kanału. Wyniki badań na temat przyrostu temperatury na zewnętrznej powierzchni korzeni zębów o cienkich ścianach nie są jednoznaczne. W celu określenia, czy metody wypełniania kanałów gutaperką termoplastyczną w zębach o cienkich ścianach są bezpieczne dla tkanek przyzębia, wskazane jest przeprowadzenie większej liczby badań.
\end{abstract}

Słowa kluczowe: wypełnianie kanału korzeniowego, wzrost temperatury na zewnętrznej powierzchni korzenia, gutaperka termoplastyczna, zęby o cienkich ścianach korzeni.

\begin{abstract}
Modern techniques of a root canal obturation using thermoplasticized gutta-percha allow for a filling of the root canal system in three dimensions. In spite of the advantages of thermal obturation methods it is important to note that warm gutta-percha can result in a temperature increase on the external root surface. Immature teeth, teeth with thin walls (mandibular incisors) or teeth with internal resorption are complex, clinical cases, in which decision on the choice of the method should be made by the dentist. The results of the research on temperature rise of the external root surface in teeth with thin walls during root canal obturation are not conclusive. In order to evaluate the safety of warm gutta-percha methods for periodontal tissues surrounding the tooth, more research should be conducted.
\end{abstract}

Keywords: root canal obturation, temperature rise of root surface, thermoplasticized gutta-percha, teeth with thin walls.

Szczelne wypełnienie kanału korzeniowego stanowi kluczowy element prawidłowego postępowania endodontycznego. Nowoczesne metody wypełniania kanałów korzeniowych pozwalają na wypełnienie systemu kanałowego $w$ trzech wymiarach. Wiele doniesień z piśmiennictwa dowodzi o wyższości systemów wykorzystujących gutaperkę termoplastyczną nad powszechnie znaną techniką kondensacji bocznej. Al-Dewani i wsp. [1] w przeprowadzonym badaniu in vitro porównali szczelność wypełnień kanałowych wykonanych techniką kondensacji bocznej zimnej gutaperki oraz za pomocą gutaperki termoplastycznej. W badaniu wykorzystano 100 usuniętych zębów ludzkich. Wyniki badania wykazały większą szczelność wypełnień wyko- nanych z zastosowaniem gutaperki termoplastycznej. Weller i wsp. [2] wykazali, że lepszą adaptację materiału wypełniającego do ścian korzenia można uzyskać po zastosowaniu metody iniekcyjnej gutaperki (Obtura II) oraz metody z zastosowaniem termicznie uplastycznionej gutaperki na specjalnym nośniku (Thermafil), w porównaniu z metodą kondensacji bocznej gutaperki na zimno. Gencoglu [3] w badaniu in vitro porównał sześć technik wypełniania kanatów korzeniowych, oceniając zawartość gutaperki w wypełnieniu kanałowym. Metody termoplastyczne zastosowane w cytowanym badaniu (Thermafil, JS Quick-Fill, Soft Core, Microseal, System B) zapewniły większą zawartość gutaperki w wypełnieniu kanałowym w porównaniu 
z metodą kondensacji bocznej gutaperki. Natera i wsp.[4] w przeprowadzonym badaniu in vitro z zastosowaniem modelu zęba dowodzą, iż zastosowanie gutaperki uplastycznionej termicznie jest metodą pozwalającą wypełnić nierówności występujące na ścianach kanału korzeniowego. Do podobnych wniosków doszli Budd i wsp. [5], porównując jakość wypełnienia kanałowego wykonanego metodą kondensacji bocznej gutaperki oraz systemów Ultrafil i Obtura. Metody wypełniania kanałów gutaperką termoplastyczną charakteryzują się wysoką efektywnością również w przypadku zębów z resorpcją wewnętrzną korzenia. Gencoglu i wsp. [6] przeprowadzili badanie porównujące jakość wypełnienia kanałów korzeniowych z resorpcją wewnętrzną korzenia. W badaniu wykorzystano 60 zębów siecznych szczęki z wypreparowaną jamą resorpcyjną. Do wypełnienia kanałów posłużyły systemy Thermafil, JS Quick-Fill, Soft Core, System B, Microseal oraz metoda kondensacji zimnej gutaperki. Oceniono stosunek gutaperki do uszczelniacza w wypełnieniu kanałowym, obecność pustych przestrzeni oraz stopień wypełniania jamy resorpcyjnej. Autorzy badania wnioskują, że metody kondensacji rozgrzanej gutaperki (Microseal, System B) pozwalają na dokładne wypełnienie kanałów korzeniowych z resorpcją wewnętrzną. Podobne badanie in vitro przeprowadzili Goldberg i wsp. [7]. W cytowanym badaniu do wypełnienia 40 kanałów z resorpcją wewnętrzną zastosowano metodę kondensacji bocznej gutaperki, metodę hybrydową, system Obtura II oraz system Thermafil. System Obtura II uznano za najefektywniejszy w wypełnianiu jam resorpcyjnych korzeni. W badaniu in vitro przeprowadzonym przez Kroczyńską i wsp. [8] również oceniona została jakość wypełnień kanałów z resorpcją wewnętrzną korzenia. W doświadczeniu wykorzystano bloczek z przezroczystego materiału $z$ gotowym kanałem korzeniowym oraz jamą resorpcyjną zlokalizowaną w połowie długości kanału. Porównane zostały trzy metody wypełniania kanałów: System E\&Q Master (wstrzykiwanie gutaperki na gorąco), Gutta-Flow (wstrzykiwanie gutaperki na zimno) oraz metoda kondensacji bocznej gutaperki z uszczelniaczem. Jakość wypełnienia kanału oceniona została na podstawie zdjęć cyfrowych oglądanych w 50-krotnym powiększeniu. Porównano przyleganie materiału wypełniającego jamę resorpcyjną do ściany kanału oraz jednorodność materiału wypełniającego. Analiza statystyczna nie wykazała istotnych różnic w przyleganiu i jednorodności wypełnień wykonanych metodami iniekcyjnymi (E\&Q Master, Gutta-Flow), natomiast istotnie gorsze przyleganie i jednorodność stwierdzono w przypadku metody kondensacji bocznej gutaperki.

Pomimo zalet systemów gutaperki uplastycznionej termicznie należy zauważyć, że rozgrzana gutaperka wprowadzona do kanału korzeniowego powoduje wzrost temperatury na zewnętrznej powierzchni korzenia wypełnianego zęba. Choć zębina jest słabym przewodnikiem ciepła, wzrost temperatury $\circ 10^{\circ} \mathrm{C}$, w porównaniu do temperatury ciała, utrzymujący się przez 1 minutę może spowodować nieodwracalne zmiany w tkankach otaczających ząb [9]. Zależność ta została udowodniona przez Eriksson i Albrektsson w badaniu in vivo przeprowadzonym na królikach [10].

W literaturze liczne doniesienia potwierdzają, że metody wypełniania kanałów gutaperką termoplastyczną są bezpieczne dla tkanek przyzębia, gdyż nie powodują wzrostu temperatury na zewnętrznej powierzchni korzeni zębów powyżej $10^{\circ} \mathrm{C}$ [11-13]. Należy jednak zauważyć, że w ww. badaniach materiał badawczy stanowiły zęby stałe o zakończonym rozwoju korzenia, o relatywnie grubych ścianach korzenia (zęby sieczne centralne, zęby przedtrzonowe jednokanałowe).

Floren i Weller [14] przeprowadzili badanie in vitro, oceniając wpływ wypełniania kanału Systemem B na wzrost temperatury na zewnętrznej powierzchni korzenia zęba. W doświadczeniu zastosowano model zęba siecznego centralnego szczęki. Na powierzchni zewnętrznej jego korzenia umieszczono 10 czujników termopary. Czujniki umieszczono co $1 \mathrm{~mm}$, począwszy od miejsca oddalonego o $1 \mathrm{~mm}$ od wierzchołka korzenia. Przygotowany model wypełniony został 20 razy z zastosowaniem Systemu B, z użyciem upychadła rozgrzanego do temperatur od $250^{\circ} \mathrm{C}$ do $600^{\circ} \mathrm{C}$. Wzrost temperatury na zewnętrznej powierzchni korzenia tylko raz przekroczył $10^{\circ} \mathrm{C}$ i utrzymał się na tym poziomie jedynie kilka sekund. Autorzy doniesienia zwracają uwagę na wpływ grubości zębiny na wzrost temperatury podczas wypełniania kanału. W powyższym doświadczeniu większy wzrost temperatury odnotowano w koronowej części korzenia niż w okolicy wierzchołkowej korzenia. Badacze tłumaczą ten fakt znacznie cieńszą ścianą korzenia w jego koronowej części.

Zęby stałe niedojrzałe, zęby o cienkich ścianach korzenia (zęby sieczne żuchwy) lub zęby $z$ resorpcją wewnętrzną stanowią trudne sytuacje kliniczne, w których lekarz dentysta musi podjąć decyzję o metodzie wypełnienia kanału.

Clarke i wsp. [15] na podstawie zdjęć radiologicznych ocenili jakość wypełnień kanałowych wykonanych w 100 niedojrzałych zębach stałych. Autorzy stwierdzili, że zastosowanie me- 
tod termicznych do wypełnienia kanałów korzeniowych pięciokrotnie zmniejsza występowanie pustych przestrzeni w obrębie wypełnienia kanałowego, w porównaniu z kanałami wypełnionymi metodą kondensacji bocznej gutaperki na zimno. Ze względu na szerokie światło kanałów zębów stałych niedojrzałych, a w związku z tym większą ilością gutaperki potrzebną do wypełnienia kanału, autorzy proponują, aby metody termiczne były metodami z wyboru przy wypełnianiu kanałów młodych zębów stałych. Niestety, w piśmiennictwie zostało opublikowanych niewiele badań dotyczących wzrostu temperatury na zewnętrznej powierzchni korzeni zębów o cienkich ścianach.

Lipski [16] przeprowadził za pomocą kamery termowizyjnej pomiary wzrostu temperatury podczas dwuetapowego wypełniania kanałów korzeniowych systemem Obtura II. W badaniu uwzględnione zostały różnice w grubości ścian korzeni zębów. Materiał badawczy stanowiło 30 zębów, które podzielono na dwie grupy. Pierwszą grupę stanowiło 15 zębów siecznych centralnych szczęki, drugą grupę 15 zębów siecznych centralnych żuchwy. Pomiar przyrostu temperatury wykonany został w obrębie całych powierzchni mezjalnych badanych korzeni zębów. W grupie pierwszej średni przyrost temperatury wyniósł $8,5 \pm 2,4^{\circ} \mathrm{C}$, natomiast $w$ grupie drugiej przyrost temperatury był trzykrotnie większy $(22,1 \pm$ $\left.7,3^{\circ} \mathrm{C}\right)$. Różnica pomiędzy wynikami w grupach była istotna statystycznie. Autor doniesienia opisuje wystąpienie dwóch pików temperatury podczas wypełniania kanałów systemem Obtura II. Pierwszy pik $\left(5,9^{\circ} \mathrm{C}\right.$ dla grupy pierwszej i $13,2^{\circ} \mathrm{C}$ dla grupy drugiej) wystąpił podczas aplikacji pierwszej porcji rozgrzanej gutaperki w obręb wierzchołkowej części kanału. Drugi wzrost temperatury $\left(8,5^{\circ} \mathrm{C}\right.$ i $\left.22,1^{\circ} \mathrm{C}\right)$ pojawił się podczas aplikacji materiału do środkowej i koronowej części kanału. Różnice w ww. wartościach autor wyjaśnia większą ilością gutaperki potrzebną do wypełnienia części środkowej i koronowej kanału oraz cieńszą zębiną korzeniową w tym obszarze korzenia zęba. W innym badaniu przeprowadzonym przez tego samego autora [17] w warunkach in vitro poddanych zostało 45 zębów ludzkich. Metodą wypełniania kanałów zastosowaną w doświadczeniu był System B, składający się z końcówki będącej nośnikiem ciepła, rozgrzewającym gutaperkę w kanale do $200^{\circ} \mathrm{C}$. Materiał badawczy podzielono na 3 grupy (zęby sieczne centralne szczęki, kły szczęki oraz zęby sieczne centralne żuchwy). Jedynie w zębach siecznych żuchwy przyrost temperatury na zewnętrznej powierzchni korzeni wyniósł ponad $10^{\circ} \mathrm{C}$. Zależność pomiędzy grubością zębiny a wzrostem temperatury była wyraźna również w zębach siecznych żuchwy i kłach szczęki. Na powierzchniach mezjalnych korzeni zanotowano większe przyrosty temperatury niż na powierzchniach przedsionkowych, gdzie grubość zębiny jest anatomicznie większa. W zębach siecznych centralnych szczęki, gdzie grubość zębiny jest porównywalna w obrębie ściany mezjalnej i przedsionkowej, nie stwierdzono statystycznie istotnej różnicy w przyrostach temperatur. Zhou i wsp. [18] wykonali model zęba trzonowego dolnego wraz $z$ więzadłem ozębnej i kością wyrostka otaczającą ząb. Pomiaru przyrostu temperatury na modelu zęba trzonowego dolnego dokonano podczas wypełniania kanałów za pomocą Systemu B i Obtura II. Największy przyrost temperatury wystąpił w „niebezpiecznej strefie”, czyli w okolicy furkacji korzeni, gdzie zębina korzeniowa jest najcieńsza. Przy trzysekundowej aktywacji upychacza Systemu B temperatura na powierzchni furkacji wyniosła $46,9^{\circ} \mathrm{C}$. Przy czterosekundowej aktywacji przyrost temperatury wyniósł powyżej $10^{\circ} \mathrm{C}$, czyli przekroczył dopuszczalną granice bezpieczeństwa dla tkanek przyzębia. System gutaperki iniekcyjnej Obtura II nie spowodował przyrostu temperatury powyżej $10^{\circ} \mathrm{C}$, dlatego autorzy uznali go za bezpieczny dla tkanek otaczających ząb.

Lee i wsp. [19] porównali wzrost temperatury na zewnętrznej powierzchni korzeni, $2 \mathrm{~mm}$ poniżej połączenia szkliwno-cementowego. W badaniu wykorzystano 30 zębów ludzkich podzielonych na 3 grupy (zęby sieczne szczę$\mathrm{ki}$, jednokanałowe zęby przedtrzonowe, zęby sieczne żuchwy). Do wypełnienia kanałów korzeniowych posłużył System B, system Touch'n'Heat oraz metoda pionowej kondensacji gorącej gutaperki. Każdy z badanych zębów wypełniony został kolejno każdym z systemów. Autorzy doświadczenia dowodzą, iż przyrosty temperatur na zewnętrznej powierzchni korzeni zębów siecznych żuchwy w każdej z metod były wyższe niż w innych grupach. Różnica ta była istotna statystycznie. Biorąc pod uwagę wszystkie grupy zębów należy stwierdzić, że jedynie System B okazał się bezpieczny dla tkanek otaczających ząb, ponieważ nie spowodował wzrostu temperatury powyżej $10^{\circ} \mathrm{C} w$ żadnym $z$ badanych zębów. Beraldo i wsp. [20] porównali trzy techniki wypełniania kanałów - TC System (system gutaperki iniekcyjnej), Touch'n'Heat, oraz technikę Taggera, w których wykorzystuje się nośnik ciepła uplastyczniający gutaperkę w kanale korzeniowym. Na podstawie zebranych 
wyników autorzy badania wnioskują, iż systemy, w których do kanału korzenia wprowadzane jest narzędzie uplastyczniające gutaperkę, powodują wyższy wzrost temperatury na zewnętrznej powierzchni korzeni zębów. Autorzy badania zauważają również wpływ grubości zębiny na wzrost temperatury na zewnętrznej powierzchni korzeni zębów. Ulusoy i wsp. [21] przeprowadzili badanie in vitro dotyczące wzrostu temperatury na zewnętrznej powierzchni korzeni zębów z resorpcją wewnętrzną. W 30 zębach przedtrzonowych wypreparowano jamy resorpcyjne. Grupe kontrolną stanowiło 30 zębów przedtrzonowych bez resorpcji wewnętrznej. Do badania wykorzystano systemy gutaperki termoplastycznej: Obtura I, Soft-core, System B. Pomiar temperatury wykonany został w 5 zębach z resorpcją i w 5 zębach kontrolnych. Najwyższy przyrost temperatury na zewnętrznej powierzchni ko- rzeni zanotowano dla Systemu B, w przypadku resorpcji w części przyszczytowej i środkowej korzenia. Przyrost temperatury powyżej $10^{\circ} \mathrm{C}$ zarejestrowano w przypadku stosowania Systemu B i Obtura II w zębach z resorpcją. System Soft-core, w którym gutaperka wprowadzana jest do kanału za pomocą plastikowego nośnika, nie spowodował wzrostu powyżej $10^{\circ} \mathrm{C}$ w żadnym z badanych zębów. System B spowodował wzrost powyżej $10^{\circ} \mathrm{C}$ również w zebach bez resorpcji wewnętrznej korzenia. Autorzy wnioskują, że grubość ścian zębiny ma wpływ na przyrost temperatury na zewnętrznej powierzchni korzeni podczas wypełniania kanału gutaperką termoplastyczną. Do odmiennych wniosków doszli Barkhordar i wsp.[22], którzy przeprowadzili badanie in vitro na 60 usuniętych zębach siecznych szczęki i żuchwy. Do wypełnienia kanałów korzeniowych zębów zastoso-

Tabela 1. Wady i zalety wypełniania kanałów gutaperką termoplastyczną

Table 1. Advantages and disatvantages of root canal obturation with thermoplasticized gutta-percha

\begin{tabular}{|c|c|c|}
\hline Autor (rok) & Wady & Zalety \\
\hline Al-Dewani i wsp. (2000) & $\begin{array}{l}\text { Prawdopodobieństwo przepchnięcia uszczelniacza } \\
\text { i gutaperki poza otwór wierzchołkowy korzenia zęba }\end{array}$ & $\begin{array}{l}\text { Szczelniejsze wypełnienie kanału korzeniowego w porównaniu } \\
\text { z techniką kondensacji bocznej gutaperki }\end{array}$ \\
\hline Weller i wsp. (1997) & $\begin{array}{l}\text { Trudność w wypełnieniu wierzchołkowej części } \\
\text { kanału w przypadku stosowania systemu gutaperki } \\
\text { uplastycznionej na specjalnym nośniku (Thermafil) }\end{array}$ & $\begin{array}{l}\text { Bardzo dobra adaptacja gutaperki do ścian kanału, jednorod- } \\
\text { na struktura wypełnienia kanałowego w przypadku techniki } \\
\text { iniekcyjnej (Obtura II) }\end{array}$ \\
\hline Budd i wsp. (1991) & $\begin{array}{l}\text { Prawdopodobieństwo przepchnięcia uszczelniacza } \\
\text { i gutaperki poza otwór wierzchołkowy korzenia. }\end{array}$ & $\begin{array}{l}\text { Bardzo dobra adaptacja gutaperki do ścian kanału korzenio- } \\
\text { wego; jednorodne wypełnienie kanału }\end{array}$ \\
\hline Natera i wsp. (2011) & $\begin{array}{l}\text { Niezadowalające wypełnienie nierówności w obrębie } \\
\text { wierzchołkowej części kanału korzeniowego w przy- } \\
\text { padku zastosowania techniki continous wave }\end{array}$ & $\begin{array}{l}\text { Dokładne wypełnienie nierówności występujących w obrębie } \\
\text { ściany kanału korzeniowego w przypadku zastosowania } \\
\text { zmodyfikowanej techniki gutaperki iniekcyjnej }\end{array}$ \\
\hline $\begin{array}{l}\text { Kroczyńska i wsp. } \\
\text { (2013) }\end{array}$ & & $\begin{array}{l}\text { Szczelne i jednorodne wypełnienie kanałów z resorpcją we- } \\
\text { wnętrzną korzenia za pomocą technik iniekcyjnych gutaperki } \\
\text { (E\&Q Master, Gutta Flow) }\end{array}$ \\
\hline Gencoglu i wsp. (2008) & $\begin{array}{l}\text { Systemy gutaperki uplastycznionej na nośniku (Ther- } \\
\text { mafil, Quick-fill, Soft-core) nie pozwalają na szczelne } \\
\text { wypełnienie resorpcji wewnętrznej korzenia }\end{array}$ & $\begin{array}{l}\text { Możliwość szczelnego wypełnienia kanałów z resorpcją we- } \\
\text { wnętrzną korzenia za pomocą techniki kondensacji rozgrzanej } \\
\text { gutaperki (Microseal, System B) }\end{array}$ \\
\hline Floren i wsp. (1999) & $\begin{array}{l}\text { Możliwość termicznego uszkodzenia tkanek otacza- } \\
\text { jących ząb w przypadku zastosowania temperatury } \\
\text { urządzenia (System B) powyżej } 250^{\circ} \mathrm{C}\end{array}$ & \\
\hline Clarke i wsp. (2015) & & $\begin{array}{l}\text { Jednorodne wypełnienie szerokich kanałów korzeniowych } \\
\text { w zębach stałych niedojrzałych }\end{array}$ \\
\hline Lipski (2005) & $\begin{array}{l}\text { Możliwość termicznego uszkodzenia tkanek } \\
\text { otaczających ząb w przypadku wypełniania kanałów } \\
\text { z cienkimi ścianami korzeniowymi }\end{array}$ & \\
\hline Zhou i wsp. (2010) & $\begin{array}{l}\text { Możliwość termicznego uszkodzenia tkanek przy- } \\
\text { zębia w przypadku stosowania systemu z gorącym } \\
\text { upychaczem (System B) w korzeniach z cienkimi } \\
\text { ścianami }\end{array}$ & $\begin{array}{l}\text { System kondensacji rozgrzanej gutaperki (Obtura) jest } \\
\text { bezpieczny dla tkanek przyzębia - nie powoduje wzrostu } \\
\text { temperatury na zewnętrznej powierzchni korzenia powyżej } \\
\text { wartości krytycznej }\end{array}$ \\
\hline Lee i wsp. (1998) & $\begin{array}{l}\text { Możliwość termicznego uszkodzenia tkanek } \\
\text { przyzębia w przypadku zębów z cienkimi ścianami } \\
\text { korzeniowymi (zęby sieczne żuchwy) }\end{array}$ & $\begin{array}{l}\text { System B jest bezpieczny dla tkanek przyzębia - nie powoduje } \\
\text { wzrostu temperatury na zewnętrznej powierzchni korzenia } \\
\text { powyżej wartości krytycznej }\end{array}$ \\
\hline Barkhordar i wsp. (1990) & & $\begin{array}{l}\text { Technika kondensacji rozgrzanej gutaperki (Obtura, Ultrafil) } \\
\text { jest bezpieczna dla tkanek przyzębia - nie powoduje wzrostu } \\
\text { temperatury powyżej wartości krytycznej }\end{array}$ \\
\hline
\end{tabular}


wano metodę pionowej kondensacji gorącej gutaperki, system Obtura oraz system Ultrafil. Każdą z technik badano z użyciem uszczelniacza i bez jego zastosowania. Materiał badawczy podzielono na 6 grup po 10 zębów. Pomiar przyrostu temperatury na zewnętrznej powierzchni korzeni zarejestrowano za pomocą termopary, której czujnik umieszczony został $2 \mathrm{~mm}$ od wierzchołka każdego korzenia. Po wypełnieniu kanałów korzeniowych badacze dokonali pomiaru grubości zębiny i cementu w każdym zębie. Autorzy cytowanego badania nie stwierdzili korelacji pomiędzy grubością zębiny a wzrostem temperatury na zewnętrznej powierzchni korzeni podczas wypełniania kanałów uplastycznioną cieplnie gutaperką. Bechnia i McDonald [23] również nie potwierdzają wpływu anatomii i morfologii korzeni zębów na zmiany temperatury na ich powierzchni. W badaniu in vitro wykorzystano 60 usuniętych zębów ludzkich (zęby sieczne centralne szczęki oraz pierwsze zęby trzonowe szczęki). Materiał badawczy podzielono na 4 grupy - zęby sieczne szczęki, korzenie policzkowe bliższe, korzenie policzkowe dalsze oraz korzenie podniebienne zębów trzonowych szczęki. Do wypełnienia kanałów korzeniowych zastosowano system Thermafil Plus. Pomiarów temperatury dokonano za pomocą kamery termowizyjnej. Analiza statystyczna nie wykazała różnic w przyrostach temperatur pomiędzy badanymi grupami. Autorzy wnioskują więc, że morfologia korzeni nie ma istotnego klinicznie wpływu na wzrost temperatury występujący na zewnętrznej powierzchni korzeni podczas wypełniania kanałów systemem Thermafil Plus.

Wyniki badań dotyczące przyrostu temperatury na zewnętrznej powierzchni korzeni zębów o cienkich ścianach nie są jednoznaczne. Różnice we wnioskach wyciągniętych przez badaczy wynikają z zastosowania różnych metod pomiaru temperatury, różnorodności materiału badawczego oraz zastosowanych systemów do wypełniania kanałów korzeniowych. Wnioski z cytowanych badań, w postaci wad i zalet wypełniania kanałów gutaperką termoplastyczną, zostały ujęte w tabeli 1. Wydaje się, że wskazane byłoby przeprowadzenie dodatkowych badań w celu sprawdzenia, czy metody wypełniania kanałów gutaperką termoplastyczną są bezpieczne dla tkanek otaczających zęby o cienkich ścianach korzeni.

\section{Oświadczenia}

Oświadczenie dotyczące konfliktu interesów

Autorzy deklarują brak konfliktu interesów w autorstwie oraz publikacji pracy.
Źródła finansowania

Autorzy deklarują brak źródeł finansowania.

\section{Piśmiennictwo}

[1] Al-Dewani N, Hayes SJ, Howell Dummer PM. Comparsion of laterally condensed and low-temperature thermoplasticized gutta-percha root fillings. J Endod. 2000;26(12):733-738.

[2] Weller RN, Kimbrough WF, Anderson RW. A comparison of thermoplastic obturation techniques: adaptation to the canal walls. J Endod. 1997;23(11):703-706.

[3] Gencoglu N. Comparison of 6 different gutta-percha techniques (part PII): Thermafil, JQuick-Fill, Soft Core, Microseal, System B, and lateral condensation. Oral Surg Oral Med Oral Pathol Oral Radiol. 2003;96(1):91-95.

[4] Natera M, Pileggi R, Nair U. A comparison of two gutta-percha obturation techniques to replicate canal irregularities in a split-tooth model. Oral Surg Oral Med Oral Pathol Oral Radiol. 2011;112(5): e29-e34.

[5] Budd C, Weller R, Kulild J. A comparison of thermoplasticized injectable gutta-percha obturation techniques. J Endod. 1991;17(6):260-264.

[6] Gencoglu N, Yildirim T, Garip Y, Karagenc B, Yilmaz H. Effectiveness of different gutta-percha techniques when filling experimental internal resorptive cavities. Int Endod J. 2008;41(10):836-842.

[7] Goldberg F, Massone E, Esmoris M, Alfie D. Comparison of different techniques for obturating experimental internal resorptive cavities. Dent Traumatol. 2000;16(3):116-121.

[8] Kroczyńska P, Gaj E, Dura W, Górski M, Lipski M. Ocena jakości wypełnienia kanałów korzeniowych z resorpcją wewnętrzna. Mag Stomatol. 2013;23(7-8):160- 164.

[9] Eriksson A, Albrektsson T, Grane B, MQueen D. Thermal injury to bone. A vital-microscopic description of heat effects. Int J Oral Surg. 1982;11(2):115-121.

[10] Eriksson AR, Albrektsson T. Temperature threshold levels for heat-induced bone tissue injury: A vital-microscopic study in the rabbit. J Prosthet Dent. 1983 Jul;50(1):101-107.

[11] Venturi M, Pasquantonio G, Falconi M, Breschi L. Temperature change within gutta-percha induced by the System-B Heat Source. Int Endod J. 2002;35(9):740-746.

[12] Weller R, Koch K. In vitro radicular temperatures produced by injectable thermoplasticized gutta-percha. Int Endod J. 1995;28(2):86-90.

[13] Sweatman T, Baumgartner J, Sakaguchi R. Radicular temperatures associated with thermoplasticized gutta-percha. J Endod. 2001;27(8):512-515.

[14] Floren J, Weller R, Pashley D, Kimbrough W. Changes in root surface temperatures with in vitro use of the system B Heat Source. J Endod. 1999;25(9):593-595.

[15] Clarke P, Jones A, Jarad F, Albadri S. Technical outcome of root canal treatment on permanent teeth in children: a retrospective study. Eur Arch Paediatr Dent. 2015;16(5):409-415.

[16] Lipski M. In vitro infrared thermographic assessment of root surface temperatures generated by high-temperature thermoplasticized injectable gutta-percha obturation technique. J Endod. 2006;32(5):438-441.

[17] Lipski M. Root surface temperature rises during root canal obturation, in vitro, by the continuous wave of condensation technique using System B Heat Source. Oral Surg Oral Med Oral Pathol Oral Radiol. 2005;99(4):505-510.

[18] Zhou X, Chen Y, Wei X, Liu L, Zhang F, Wu W, et al. Heat transfers to periodontal tissues and gutta-percha during thermoplasticized root canal obturation in a finite element analysis model. Oral Surg Oral Med Oral Pathol Oral Radiol. 2010;110(2):257-263.

[19] Lee F, Van Cura J, BGole E. A comparison of root surface temperatures using different obturation heat sources. J Endod. 1998;24(9):617-620.

[20] Beraldo D, Pereira K, Yoshinari F, Pinto J, de Abreu Mateus T, Zafalon E. Temperature changes on external root surfaces with the use of several thermoplastic filling techniques. J Endod. 2016;42(7):1131-1134. 
[21] Ulusoy Ö, Yılmazoğlu M, Görgül G. Effect of several thermoplastic canal filling techniques on surface temperature rise on roots with simulated internal resorption cavities: an infrared thermographic analysis. Int Endod J. 2015;48(2):171-176.

[22] Barkhordar R, Goodis H, Watanabe L, Koumdjian J. Evaluation of temperature rise on the outer surface of teeth during root canal obturation techniques. Quintessence Int. 1990;21(7):585-588.

[23] Behnia A, McDonald N. In vitro infrared thermographic assessment of root surface temperatures generated by the thermafil plus system. J Endod. 2001;27(3):203-205.
Zaakceptowano do edycji: 2017-04-12

Zaakceptowano do publikacji: 2017-04-22

\section{Adres do korespondencji:}

Anna Gmerek

ul. Janickiego 16A/12, 71-270 Szczecin

tel.: +48668188335

e-mail: ania@gmerek.eu 